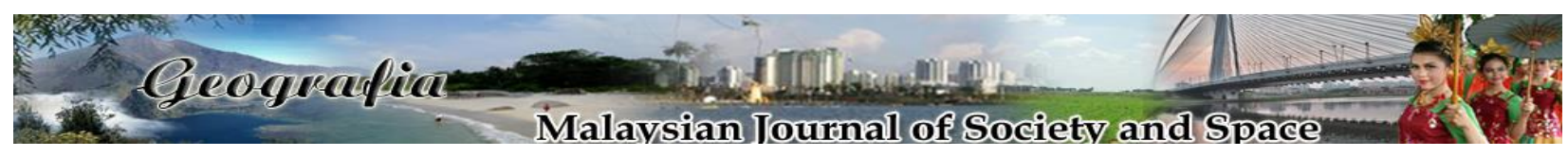

\title{
Analisis perubahan guna tanah Negeri Sembilan melalui aplikasi Sistem Maklumat Geografi (GIS)
}

\author{
Nur Syabeera Begum Nasir Ahmad, Firuza Begham Mustafa \\ Jabatan Geografi, Fakulti Sastera dan Sains Sosial, Universiti Malaya \\ Correspondence: Firuza Begham Mustafa (email: firuza@um.edu.my)
}

Received: 05 December 2018; Accepted: 14 January 2019; Publish: 22 February 2019

\begin{abstract}
Abstrak
Perubahan guna tanah sesuatu kawasan yang menuntut eksploitasi terhadap alam sekitar telah menimbulkan pelbagai isu berkaitan dengan guna tanah seperti kawasan hutan telah digantikan dengan kawasan perbandaran dan kawasan pertanian. Tujuan kajian ini dijalankan adalah untuk mengkaji pola perubahan guna tanah di Negeri Sembilan daripada perspektif ruang dan masa antara tahun 1961 dan 2014, serta mengkaji faktor pendorong perubahan guna tanah yang berlaku. Data guna tanah yang digunakan dalam kajian ini ialah peta guna tanah Negeri Sembilan tahun 1961 dan 2014 serta data sekunder lain. Guna tanah di kawasan kajian telah dibahagikan kepada empat jenis iaitu guna tanah bandar, guna tanah pertanian, guna tanah hutan dan guna tanah lain-lain. Hasil analisis menggunakan ArcGIS 9.3 telah menunjukkan perubahan yang ketara dalam setiap jenis guna tanah. Proses analisis tindanan peta dilakukan bagi mengetahui perubahan keluasan yang berlaku pada setiap jenis guna tanah. Guna tanah pertanian mengalami perubahan paling tinggi dari tahun 1961 sehingga 2014, manakala guna tanah perbandaran mengalami perubahan paling rendah. Guna tanah hutan pula telah mengalami pengurangan dari tahun 1961 sehingga 2014. Perubahan guna tanah berlaku disebabkan oleh beberapa faktor iaitu penambahbaikan polisi melalui Akta Perancangan Bandar dan Desa 1976, pertambahan populasi penduduk, jaringan pengangkutan, ekonomi dan konurbasi bandar Kuala Lumpur. Kajian ini dilihat dapat membantu dalam proses pembuatan keputusan bagi mengawal perubahan dan perancangan guna tanah yang berlaku dalam cara yang lebih sistematik dan memastikan kemampanan alam sekitar pada masa akan datang.
\end{abstract}

Kata kunci: analisis guna tanah, ArcGIS, faktor perubahan, guna tanah, Sistem Maklumat Geografi, pola perubahan 


\title{
Analysis of land use changes of Negeri Sembilan using Geographic Information System (GIS)
}

\begin{abstract}
The land use changes of an area, an indication of exploitation on the environment, have led to various issues related to land use such as forest areas have been replaced with urban areas and agricultural areas. The purpose of this study was to examine the land use changes in Negeri Sembilan in terms of space and time between the year of 1961 and 2014 as well as to study the driving factors of land use changes. Land use data obtained in this analysis is a land use map of Negeri Sembilan in 1961 and 2014 as well as other secondary data. Land use in the study area was divided into four types of land use which are urban land use, agriculture land use, forest land use and other land use. The analysis using Arc GIS 9.3 has demonstrated a significant change in each type of land use. The map overlay analysis was conducted to determine the total change area for each type of land use. Agriculture land use has the highest changes from 1961 to 2014 and the urban land use has the lowest changes. While forest land use has decreased from 1961 to 2014. Land use changes occur due to several factors such as the improvement of the policy through "Akta Perancangan Bandar dan Desa 1976", the increase in population, transportation links, economy and Kuala Lumpur conurbation. This study is seen to assist in decision making processes to control changes in land use and land use planning in a more systematic way to ensure environmental sustainability in the future.
\end{abstract}

Keywords: land use analysis, ArcGIS, change factor, land use, Geographic Information System, change pattern

\section{Pengenalan}

Sejak zaman pra-sejarah manusia mula beradaptasi dengan sumber semula jadi dan alam sekeliling untuk meneruskan kelangsungan hidup. Penerokaan dan penggunaan sumber tanah adalah prinsip asas dalam pembangunan hidup manusia. Manusia pada zaman Neolitik mengubah persekitaran mereka bagi mendapatkan hasil. Seperti contoh, mereka mula menukar guna tanah hutan kepada guna tanah kediaman serta pertanian bagi mendapatkan kehidupan yang lebih selesa. Sehingga kini, perubahan terhadap guna tanah terus berlaku bagi memenuhi kehendak serta keperluan manusia. Perubahan guna tanah merupakan satu proses yang berlaku secara berterusan, ia merangkumi semua jenis pembangunan diatas permukaan tanah seperti guna tanah untuk pertanian, komersial, industri, perumahan, perbandaran dan lain-lain.

Perubahan guna tanah berlaku akibat tuntutan keperluan penduduk sentiasa berubah dari semasa ke semasa untuk menjalankan aktiviti tertentu yang didorong oleh faktor fizikal, ekonomi dan sosial. Oleh itu, isu penggunaan tanah adalah perkara yang penting untuk dikaji. Pemahaman yang mendalam tentang perubahan alam sekeliling sama ada secara beransur-ansur atau drastik akan memberikan kefahaman yang berharga mengenai interaksi alam semulajadi dengan aktiviti manusia (Bakr et al., 2010). Kebelakangan ini, perubahan terhadap guna tanah telah menjadi salah satu isu penting dalam kajian terhadap perubahan alam sekitar global (Yong et al., 2017). Pembangunan yang dilakukan semestinya memberikan impak terhadap alam sekitar fizikal dan 
menjejaskan kestabilan ekosistem. Persoalan pembangunan dan alam sekitar adalah melibatkan pertimbangan antara perancangan pembangunan dan pemuliharaan alam sekitar (Tuan Pah Rokiah \& Hamidi, 2016). Namun begitu, perubahan yang dilakukan tidak dapat mengelak daripada meninggalkan kesan terhadap alam sekitar dan manusia akan terus melakukan perubahan demi perubahan bagi mencapai kemajuan yang lebih tinggi. Kunci utama dalam mengekalkan kesejahteraan alam sekitar di samping terus melakukan pembangunan bagi tujuan pemodenan adalah kesimbangan. Keseimbangan antara alam sekitar dan pembangunan harus sentiasa dipantau agar kedua-dua elemen dapat terus dinikmati pada masa kini dan generasi akan datang.

Sistem Maklumat Geografi (Geographic Information System/ GIS) merupakan antara analisis yang dilihat mampu membantu dalam mengekalkan keseimbangan antara kemajuan pembangunan dan kesejahteraan alam sekitar. GIS dapat memaparkan secara visual perubahanperubahan yang berlaku terhadap guna tanah. Oleh itu, langkah-langkah yang berkesan dapat dirancang bagi memastikan keseimbangan yang dicari dapat dicapai. Objektif kajian ini ialah mengenal pasti jenis guna tanah Negeri Sembilan pada tahun 1961 dan 2014 menggunakan aplikasi GIS, menganalisis pola perubahan guna tanah di Negeri Sembilan dari tahun 1960 dan tahun 2014 serta menghuraikan faktor-faktor yang menyumbang kepada perubahan guna tanah tersebut.

\section{Kajian literatur}

Guna tanah merujuk kepada penggunaan, pengurusan serta transformasi manusia terhadap tanah berdasarkan ciri-ciri fizikal dan ekologi serta keperluan manusia termasuk keperluan asas, pembangunan sosioekonomi rekreasi dan sebagainya (Bajocco et al., 2012; Pijanowski \& Robinson, 2011; Pourebrahim et al., 2015; Zhao et al., 2017). Sistem guna tanah merupakan sebuah sistem yang kompleks dan dinamik namun boleh dikawal (Pei \& Pan, 2010) berpandukan pengurusan yang tertentu. Putman (1975) mendefinisikan guna tanah sebagai penggunaan tanah yang tertakluk kepada beberapa prinsip iaitu guna tanah secara optimum, guna tanah untuk pelbagai tujuan dan pengeluaran secara maksimum. Guna tanah ialah sifat-sifat tanah yang mempunyai perletakan yang tetap dan terhad. Ia berubah mengikut faktor fizikal dan persekitaran yang sering merumitkan penentuan dalam penggunaannya (Rhind \& Hudson, 1980).

Perubahan guna tanah adalah kesan daripada pengaruh manusia terhadap landskap yang terjadi kerana pengubahsuaian yang ketara di dalam ekosistem (La Mela Veca et al., 2016). Hal ini jelas menunjukkan tindakan manusia merupakan antara faktor perubahan guna tanah bagi meneruskan kelangsungan hidup. Menurut Jeffers (1988), kepentingan kajian guna tanah ialah untuk mengkaji peratus perubahan guna tanah baru berbanding dengan guna tanah asal bagi memahami pola perubahan guna tanah.

Pengelasan kategori guna tanah dilakukan untuk melihat perubahan dan kehilangan tanah asal dengan lebih jelas melalui visual dan kiraan statistik dengan menggunakan kaedah dan sistem-sistem tertentu. Best (1981) telah memberikan tiga kelas utama guna tanah iaitu kawasan hutan, kawasan pertanian dan kawasan perbandaran. Manakala dalam sebuah buku yang bertajuk Land transformation in agriculture, Wolman dan Fournier (1987) telah mengkategorikan guna tanah kepada empat iaitu tanah gurun, padang rumput, tanah hutan dan tanah bukan pertanian. Basavarajappa et al. (2014) mengklasifikasikan guna tanah kepada lima kelas utama iaitu kawasan tepu bina, kawasan pertanian, kawasan hutan, badan air serta tanah yang tidak 
digunakan. Xia et al. (2018) pula membahagikan guna tanah kepada tujuh iaitu kawasan pertanian, hutan, padang rumput, badan air, kawasan tepu bina, tanah yang tidak digunakan dan kawasan tanah lembap.

Kajian ini mengunakan kaedah pengelasan guna tanah oleh Jabatan Pertanian Malaysia. Menurut Jabatan Pertanian Malaysia terdapat empat jenis guna tanah utama iaitu guna tanah perbandaran, guna tanah pertanian, guna tanah perhutanan dan guna tanah lain-lain. Guna tanah perbandaran merangkumi kawasan kediaman, kawasan perkuburan, jalan raya, lombong, kuari dan laluan talian elektrik. Manakala guna tanah pertanian ialah kawasan perkebunan, kawasan rumput terbiar, penanaman tanaman kekal dan tanaman singkat. Kawasan hutan pula meliputi hutan, belukar, hutan paya dan kawasan timbunan balak. Guna tanah lain-lain merangkumi tanah lapang dan kosong.

Perubahan guna tanah yang berlaku telah menimbulkan beberapa isu dari segi pola dan proses perubahan itu sendiri seperti konfigurasi ruang dan perubahannya dari masa ke masa (Petit \& Lambin, 2002) yang terhasil daripada beberapa faktor (Christopoulou et al., 2007; Jomaa et al., 2008; Paul \& Tonts, 2005; Soliman, 2004). Penyelidik tempatan dan antarabangsa telah menjalankan pelbagai kajian berkaitan dengan faktor yang membawa kepada perubahan guna tanah yang berlaku di sesebuah kawasan. Pola penggunaan tanah dilihat sebagai hasil interaksi jangka panjang antara manusia dengan alam sekitar (Bičík et al., 2015). Pelbagai kaedah kuantitatif dan kualitatif yang berbeza digunakan untuk mengesan faktor yang mendorong kepada perubahan guna tanah (Kleeman et al., 2017). Faktor yang menyumbang kepada berlakunya perubahan boleh dirumuskan kepada faktor geografi dan sosioekonomi (Zimu et al., 2018).

Pelbagai kajian mendalam mengenai guna tanah dan litupan tanah telah dijalankan pada pelbagai skala dan mencapai hasil dan keputusan yang sangat bernilai (Li \& Liu, 2017). Kajiankajian yang memberangsangkan telah dijalankan oleh beberapa pengkaji tempatan dan luar negara (Jadual 1).

Jadual 1. Kajian lepas berkaitan perubahan guna tanah dan GIS

\begin{tabular}{|c|c|}
\hline Malaysia & Luar Malaysia \\
\hline 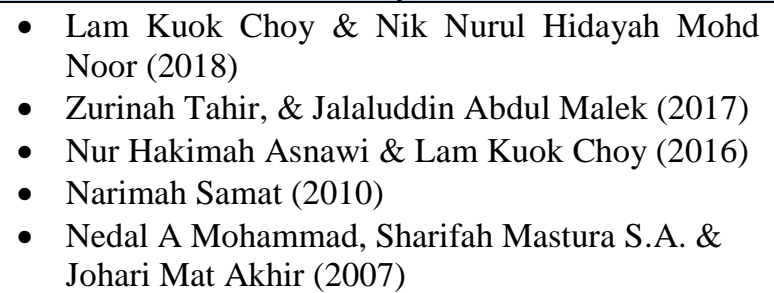 & $\begin{array}{ll}\text { - } & \text { Yafei \& Gaohuan (2017) } \\
\text { - } & \text { Meshesha, T.W., Tripathi, S.K. \& Khare, D. } \\
& \text { (2016) } \\
\text { - } & \text { Statuto, D., Cillis, G. \& Picuno, P. (2016) } \\
\text { - } & \text { Ting, L. \& Xiaojun, Y. (2015) } \\
\text { - } & \text { Dewan, A.M. \& Yamaguchi, Y. (2009) } \\
\text { - } & \text { Yuan, F. (2008) }\end{array}$ \\
\hline
\end{tabular}

\section{Metod dan kawasan kajian}

Kajian ini dilakukan menggunakan data primer dan data sekunder. Metodologi kajian ini boleh dibahagikan kepada dua bahagian iaitu pemetaan yang merangkumi analisis perubahan guna tanah di Negeri Sembilan pada tahun 1961 dan 2014 serta penyelidikan mengenai faktor-faktor perubahan guna tanah yang berlaku di Negeri Sembilan. Data primer bagi kajian ini dikumpul melalui kaedah temu bual serta serta pemerhatian di kawasan kajian. Data sekunder yang digunakan dalam kajian ini ialah peta topografi, rancangan-rancangan kerajaan, jurnal dan akhbar. 


\section{Pemetaan perubahan guna tanah}

Pembangunan pangkalan data merupakan proses utama dalam bahagian ini kerana merupakan langkah pemprosesan data melalui aplikasi GIS yang menggunakan perisian ArcGIS 9.3. Penggunaan alat GIS di dalam sesebuah kajian berupaya untuk menyelaraskan pemprosesan data, mengurangkan kos analisis dan meningkatkan ketepatan hasil kajian (Lowicki, 2009). Terdapat beberapa langkah dalam membina pangkalan data iaitu proses pengimbasan, proses georujukan, proses pendigitan dan analisis tindanan peta.

Pengimbasan merupakan teknik pertama dalam membina pangkalan data. Peta topografi yang diperolehi dari Bilik Sumber Peta Jabatan Geografi, Universiti Malaya dalam bentuk peta kertas diimbas untuk mendapatkan peta dalam bentuk digital, yang diperlukan untuk proses pendigitan. Peta yang telah diimbas ke dalam bentuk digital adalah di dalam bentuk raster. Kemudian, proses georujukan dijalankan. Georujukan ialah proses yang berfungsi bagi menentukan koordinat dan kedudukan sebenar peta pada permukaan bumi. Kaedah ini dilakukan untuk mendaftar imej yang tidak mempunyai koordinat. Setelah itu, proses pendigitan boleh dijalankan. Proses pendigitan dilakukan bagi menukarkan peta yang berbentuk raster dapat dipaparkan di dalam bentuk vektor. Proses ini merupakan proses yang rumit dan mengambil masa yang lama untuk memastikan kesempurnaan peta yang terhasil. Sebelum proses pendigitan dimulakan, shapefile harus dibuat terlebih dahulu menggunakan perisian Arc Catalog.

Melalui proses pendigitan peta, terdapat tiga fokus utama untuk didigit iaitu poligon, titik dan garisan. Penghasilan peta Negeri Sembilan pada tahun 1961 dan 2014 lebih menggunakan pendigitan poligon bagi membentuk sempadan guna tanah yang berlainan. Selain itu, pendigitan titik serta garisan juga digunakan bagi menghasilkan peta. Titik digunakan untuk mawakili beberapa lokasi seperti kampung dan garisan digunakan untuk membentuk jaringan jalan raya. Kemudian, proses analisis tindanan peta dilakukan untuk mengenalpasti kawasan yang sama tetapi mempunyai maklumat yang berbeza. Analisis ini dilakukan untuk menindan guna tanah yang berbeza iaitu guna tanah bandar, guna tanah pertanian, guna tanah lain-lain dan guna tanah hutan. Luas setiap jenis guna tanah dikira daripada lapisan tindanan yang terhasil.

\section{Faktor perubahan guna tanah Negeri Sembilan}

Faktor perubahan guna tanah telah diteliti dalam kajian ini melalui kaedah temu bual dan rujukan perpustakaan. Faktor perubahan guna tanah Negeri Sembilan dihuraikan dari segi faktor manusia. Rancangan Struktur Negeri Sembilan 2001-2020 dan Rancangan Tempatan Daerah terkini merupakan antara rujukan utama bagi mengetahui perancangan dan pelaksanaan kerajaan bagi membangunkan Negeri Sembilan yang telah memberikan kesan terhadap guna tanah di negeri tersebut. Antaranya ialah Rancangan Tempatan Daerah Seremban, Rancangan Tempatan Daerah Jempol dan Rancangan Tempatan Daerah Port Dickson. Selain itu, temubual juga dijalankan bagi mengetahui faktor-faktor perubahan guna tanah yang berlaku. Temubual dijalankan terhadap dua orang individu iaitu Pegawai Projek Khas di Jabatan Pertanian Negeri Sembilan dan Penolong Pengarah Jabatan Perancang Bandar dan Desa Negeri Sembilan. Sumber-sumber daripada internet dirujuk seperti jurnal dan akhbar atas talian. Kajian lepas dirujuk untuk menghuraikan faktor-faktor yang mempengaruhi perubahan guna tanah di Negeri Sembilan. Dalam pada itu, kaedah pemerhatian juga dijalankan di sekitar kawasan utama Negeri Sembilan bagi melihat guna tanah terkini yang mendominasi Negeri Sembilan. 


\section{Kawasan kajian}

Negeri Sembilan (Rajah 1) merupakan sebuah negeri yang terletak di pantai barat Semenanjung Malaysia. Ianya meliputi kawasan seluas $6648.99 \mathrm{~km}^{2}$ (Jabatan Perancangan Bandar dan Desa Negeri Sembilan, 2014). Ibu negerinya ialah Seremban dan Negeri Sembilan mempunyai tujuh daerah iaitu Jelebu, Jempol, Tampin, Kuala Pilah, Rembau, Port Dickson dan Seremban. Koordinat Negeri Sembilan ialah 3 $3^{\circ} 17.100^{\prime} \mathrm{U}, 101^{\circ} 56.022^{\prime} \mathrm{T}$ dan $2^{\circ} 24.948^{\prime} \mathrm{T}, 102^{\circ} 35.772^{\prime} \mathrm{T}$ (Mohd Hafiz \& Tuan Mohamad, 2016).

Terdapat kepelbagaian bentuk muka bumi di Negeri Sembilan. Kepelbagaian bentuk muka bumi membolehkan pelbagai aktiviti manusia dijalankan. Muka bumi bergunung-ganang di Negeri Sembilan tertumpu di kawasan tengah Negeri Sembilan dimana Banjaran Titiwangsa semakin menirus menghala ke Johor. Oleh itu, di bahagian timur dan barat Negeri Sembilan mempunyai bentuk muka bumi yang lebih landai berbanding kawasan tengah Negeri Sembilan. Tumpuan utama guna tanah tepu bina di Negeri Sembilan adalah di bahagian daerah Seremban, Port Dickson dan Tampin. Kawasan pertanian pula lebih kepada bahagian barat dan timur Negeri Sembilan.

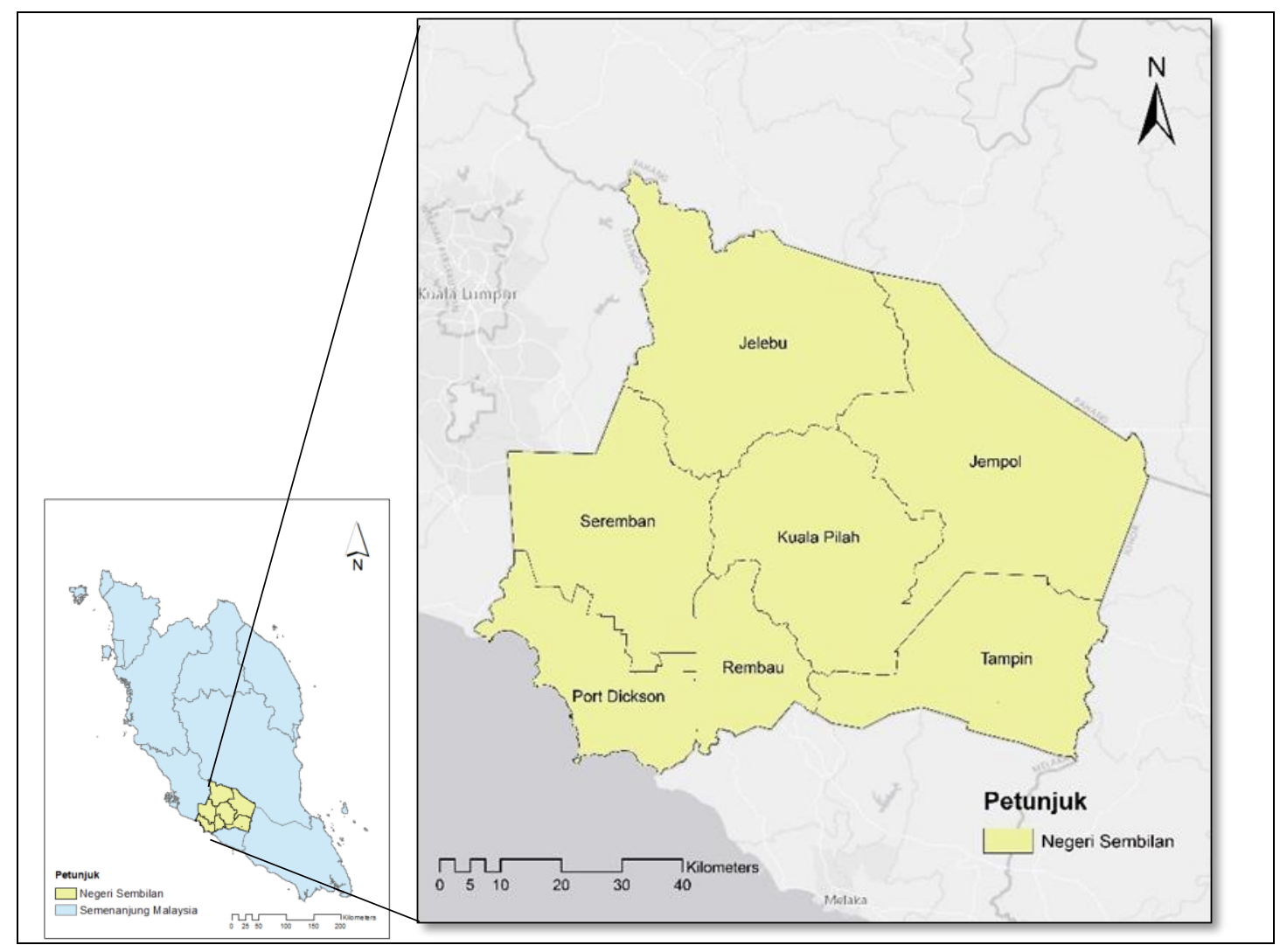

Rajah 1. Peta Negeri Sembilan 


\section{Hasil kajian dan perbincangan}

\section{Perubahan guna tanah Negeri Sembilan tahun 1961 dan 2014}

Perubahan yang ketara dapat dilihat berlaku terhadap guna tanah Negeri Sembilan. Rajah 2 dan Rajah 3 menunjukkan guna tanah di Negeri Sembilan pada tahun yang dinyatakan. Jadual 2 menunjukkan pada tahun 1961, guna tanah hutan mendominasi Negeri Sembilan iaitu sebanyak $41.15 \%$. Manakala pada tahun 2014, guna tanah pertanian pula yang mendominasi guna tanah di Negeri Sembilan iaitu mengalami peningkatan sebanyak $24.66 \%$ daripada tahun 1961. Guna tanah hutan pada tahun 2014 didapati menurun iaitu penurunan sebanyak $16.65 \%$ daripada tahun 1961. Guna tanah lain-lain pada tahun 1961 ialah seluas $1394.33 \mathrm{~km}^{2}$. Perubahan telah berlaku pada tahun 2014 iaitu penurunan kepada $225.27 \mathrm{~km}^{2}$. Hal ini terjadi kerana kebanyakan tanah kosong dan tanah rizab telah dibangunkan sehingga tahun 2014. Guna tanah bandar mengalami perubahan yang paling kecil iaitu peningkatan hanya sebanyak $10.07 \%$. Kemajuan yang berlaku telah membawa perubahan kepada guna tanah bandar Negeri Sembilan.

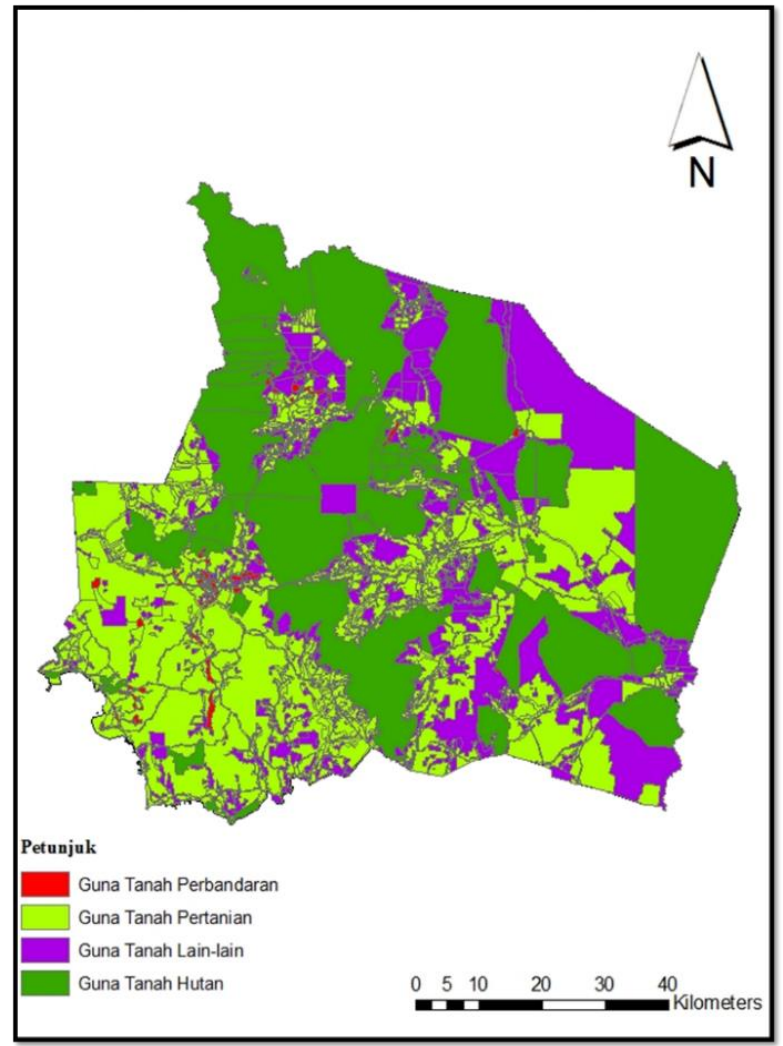

Rajah 2. Peta guna tanah Negeri Sembilan tahun 1961

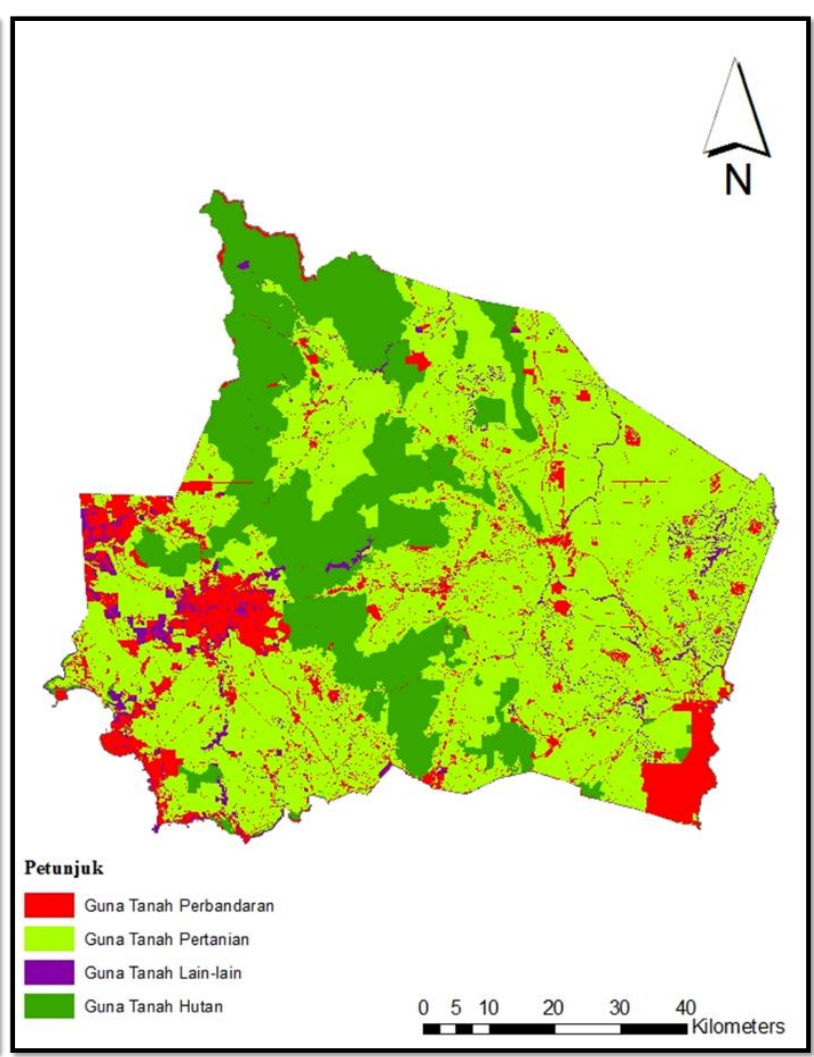

Rajah 3. Peta guna tanah Negeri Sembilan tahun 2014 
Jadual 2. Penggunaan tanah Negeri Sembilan dan jumlah perbezaan perubahan guna tanah

\begin{tabular}{lcccccc}
\hline \multicolumn{1}{c}{ Jenis guna tanah } & \multicolumn{2}{c}{ 1961 } & \multicolumn{2}{c}{ 2014 } & \multicolumn{2}{c}{ Perubahan keluasan } \\
\cline { 2 - 7 } & \multicolumn{2}{c}{ Keluasan } & \multicolumn{2}{c}{ Keluasan } & \multicolumn{2}{c}{ Keluasan } \\
& $\left(\mathbf{k m}^{2}\right)$ & $(\boldsymbol{\%})$ & $\left(\mathbf{k m}^{2}\right)$ & $(\boldsymbol{\%})$ & $\left(\mathbf{k m}^{2}\right)$ & $(\mathbf{\%})$ \\
\hline Guna tanah bandar & 47.74 & 0.73 & 718.27 & 10.80 & +670.53 & +10.07 \\
Guna tanah pertanian & 2381.14 & 36.65 & 4076.17 & 61.31 & +1698.03 & +24.66 \\
Guna tanah lain-lain & 1394.33 & 21.46 & 225.27 & 3.39 & -1169.06 & -18.07 \\
Guna tanah hutan & 2673.03 & 41.15 & 1628.33 & 24.50 & -1044.70 & -16.65 \\
\hline
\end{tabular}

Pada tahun 2014, berlaku pengurangan guna tanah hutan Negeri Sembilan kerana kebanyakan kawasan hutan telah dibersihkan atas tujuan aktiviti pertanian dan perbandaran. Pada tahun 1961, guna tanah pertanian utama di Negeri Sembilan ialah padi dan getah serta beberapa tanaman lain. Namun pada tahun 2014, guna tanah pertanian di Negeri Sembilan didominasi oleh tanaman kelapa sawit. Selain itu, pada tahun 1961, kawasan perumahan hanya merangkumi kawasan kampung. Namun pada tahun 2014, kawasan perumahan merangkumi kawasan kampung, kawasan perumahan berstrata, kawasan perumahan tidak berstrata dan kawasan setinggan. Hal ini menunjukkan guna tanah perbandaran yang merangkumi kawasan perumahan, kawasan perbandaran, utiliti dan kemudahan semakin meningkat pada tahun 2014.

Pada tahun 1961, Malaysia baru sahaja empat tahun mencapai kemerdekaan dan negerinegeri di Malaysia sedang membina tapak untuk mengukuhkan negeri masing-masing. Negeri Sembilan masih lagi dalam proses mencari hala tuju bagi membangunkan negeri tersebut. Oleh itu, pembangunan dijalankan mengikut keperluan dan rangka yang jelas masih belum wujud untuk dijadikan panduan. Pada tahun tersebut, penggunaan guna tanah masih mengikut corak tinggalan penjajah. Ekonomi yang dijalankan pada waktu tersebut tidak begitu meluas dan lebih banyak dijalankan mengikut keperluan kelompok-kelompok yang kecil. Pada tahun 2014, semakin banyak sumber semula jadi diterokai hasil peningkatan teknologi dan membawa kepada perubahan guna tanah di Negeri Sembilan.

\section{Faktor perubahan guna tanah Negeri Sembilan}

Terdapat beberapa faktor yang mempengaruhi perubahan guna tanah di Negeri Sembilan dari tahun 1961 sehingga 2014.

\section{a. Akta Perancangan Bandar dan Desa 1976}

Akta Perancangan Bandar dan Desa 1976 (Akta 172) merupakan akta yang diwujudkan sebagai langkah kawalan terhadap pembangunan guna tanah yang lebih lengkap. Terdapat dua jenis pelan pembangunan utama di bawah Akta 172 yang memandu pembangunan guna tanah di Negeri Sembilan iaitu Rancangan Struktur Negeri Sembilan dan Rancangan Tempatan. Rancangan Struktur Negeri merupakan suatu pernyataan bertulis yang menerangkan dasar dan cadangan-cadangan strategik negeri berkenaan dengan pemajuan dan penggunaan tanah dalam kawasan bandar dan desa (Jabatan Perancangan Bandar dan Desa Terengganu, 2018).

Rancangan Tempatan pula ialah satu dokumen rasmi yang mentafsirkan dasar-dasar dan cadangan-cadangan umum yang terkandung di dalam Rancangan Struktur kepada bentuk fizikal yang lebih terperinci dan praktikal (Jabatan Perancangan Bandar dan Desa Terengganu, 2018). Rancangan ini disediakan oleh Pihak Berkuasa Tempatan bagi kawasan-kawasan tertentu. Seksyen 18 Akta 172 menyatakan bahawa: 
“...tidak seorang pun boleh atau dibenarkan menggunakan tanah atau bangunan kecuali disahkan dengan Pelan Tempatan."

(Kementerian Perumahan dan Kerajaan Tempatan, 1976)

Merujuk kenyataan di atas, jelas menunjukkan setelah termaktubnya Akta 172 pada tahun 1976, setiap aktiviti dan perubahan yang djalankan ke atas tanah harus mendapat kelulusan daripada Pihak Berkuasa Tempatan berdasarkan pelan yang telah diperkenalkan. Ini membuktikan bahawa Rancangan Struktur serta Rancangan Tempatan memainkan peranan yang penting terhadap perubahan guna tanah yang berlaku di Negeri Sembilan. Sebelum tahun 1976, tiada panduan yang jelas mengenai penggunaan tanah dan tanah dibangunkan mengikut tuntutan serta keperluan pada waktu tersebut.

Perubahan guna tanah yang berlaku juga disebabkan oleh Rancangan Struktur Negeri Sembilan 2001-2020 yang memberi fokus pembangunan tertentu kepada setiap daerah. Pengkhususan yang diberi adalah berdasarkan kelebihan-kelebihan yang diperolehi oleh setiap daerah (Jadual 3). Pembangunan sesuatu kawasan harus dirancang dan dijalankan berpandukan Rancangan Struktur dan Rancangan Tempatan sesuatu kawasan tersebut. Oleh itu, hal ini jelas menunjukkan bahawa Rancangan Struktur dan Rancangan Tempatan di bawah Akta Perancangan Bandar \& Desa 1976 memberi impak kepada perubahan guna tanah yang berlaku di Negeri Sembilan.

Jadual 3. Fokus pembangunan daerah-daerah Negeri Sembilan

\begin{tabular}{ll}
\hline Daerah & \multicolumn{1}{c}{ Pembangunan utama yang dijalankan } \\
\hline Seremban & $\begin{array}{l}\text { Pentadbiran (E-Goverment), Institusi, Perdagangan dan Bandar Dormitori serta nilai } \\
\text { sebagai Pusat Industri 'Bio Tech' }\end{array}$ \\
Port Dickson & Bandar Dormitori, Daerah Perkhidmatan dan Pelancongan \\
Jempol & $\begin{array}{l}\text { Daerah Penyelidikan dan Pembangunan Agro, Agropolis dan Daerah agro- } \\
\text { Pelancongan, Hinterland-Bio Valley }\end{array}$ \\
Kuala Pilah & Agropolis, Industri Kecil dan Sederhana (IKS), Daerah Bersejarah, Warisan dan \\
& Budaya, Hinterland-Bio Valley \\
Tampin & Daerah Industri dan Penternakan, Bandar Dormitori, Iindustri dan Perdagangan, \\
& Hinterland-Bio Valley \\
Jelebu & Pusat Bio-Valley, Industri Kecil dan Sederhana (IKS), Daerah eko dan agro- \\
& pelancongan \\
Rembau & Pusat Pemprosesan Makanan Halal, Daerah Industri Makanan Halal, Hinterland-Bio \\
Valley
\end{tabular}

Antara faktor perubahan guna tanah berlaku adalah disebabkan oleh peningkatan populasi penduduk (Rajan \& Shibasaki, 2001). Menurut hasil temubual bersama Jabatan Perancang Bandar dan Desa Negeri Sembilan, populasi penduduk yang bertambah menyebabkan keperluan pembangunan semakin meningkat. Pertambahan jumlah penduduk yang pesat telah membawa kepada permintaan yang tinggi dan ini menimbulkan tekanan ke atas penggunaan tanah (Reis, 2008). Tekanan yang berlaku adalah hasil permintaan penduduk yang meningkat bagi menjalankan aktiviti untuk menjana ekonomi serta membina kawasan perumahan. 
Negeri Sembilan telah mengalami pertambahan penduduk dari tahun 1961 sehingga tahun 2014. Sehingga kini jumlah penduduk Negeri Sembilan telah melebihi satu juta orang. Merujuk kepada Rajah 4, berlaku peningkatan penduduk secara mendadak daripada 364,524 orang pada tahun 1957 kepada 1,029,500 orang pada tahun 2010. Pada tahun-tahun berikutnya, didapati jumlah penduduk masih meningkat tetapi dengan kadar yang perlahan.

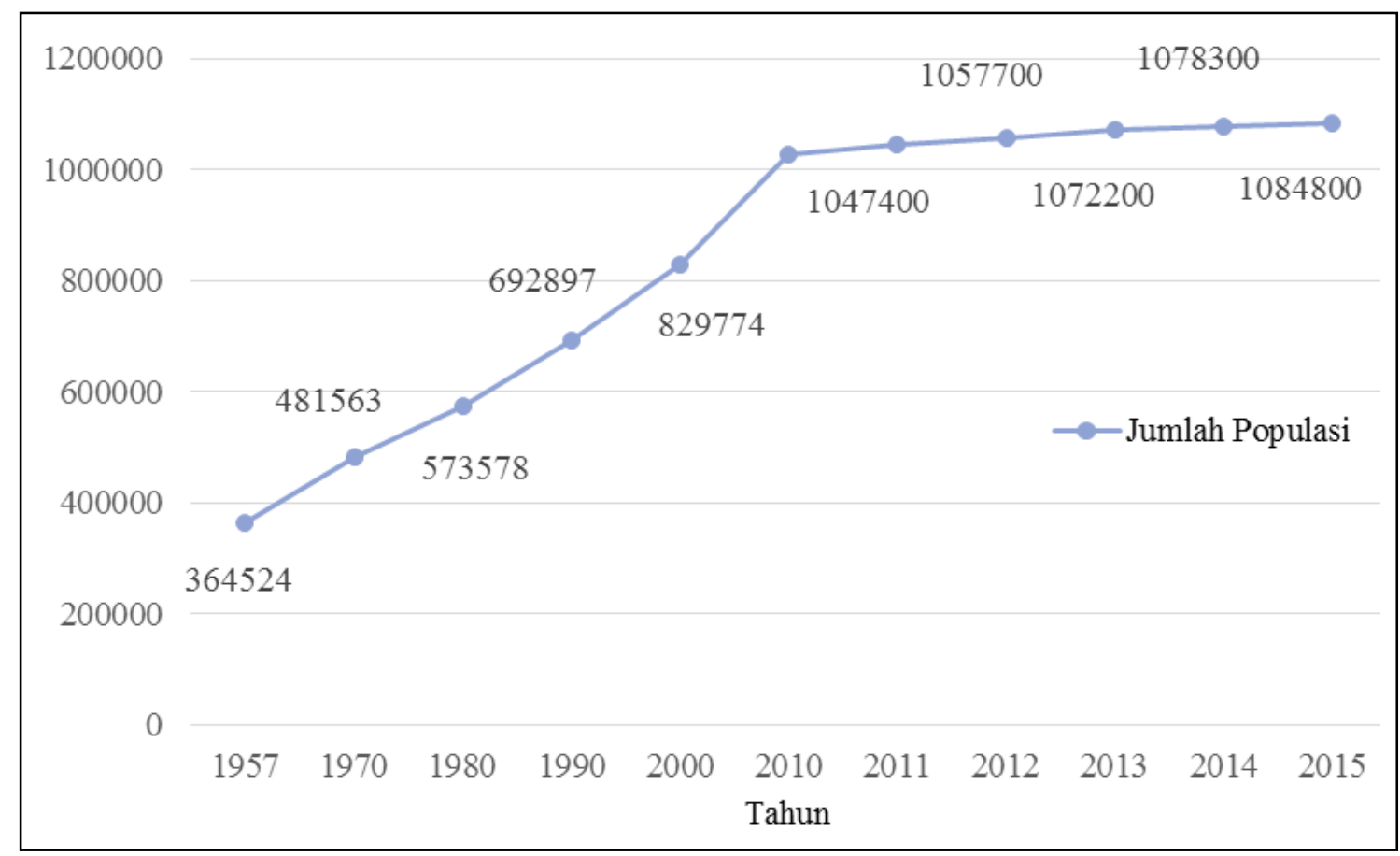

Sumber: Jabatan Perangkaan Malaysia, 2016

Rajah 4. Unjuran jumlah penduduk Negeri Sembilan

Pembuktian bahawa pertambahan populasi penduduk sememangnya memberikan impak kepada guna tanah Negeri Sembilan adalah melalui pertambahan kawasan kediaman di Negeri Sembilan. Rajah 5 menunjukkan bahawa berlaku peningkatan dalam jumlah kampung dan kawasan perumahan pada tahun 2014 berbanding tahun 1961. Selain itu, didapati pada tahun 2014 telah wujud kawasan-kawasan perumahan yang baru seperti kawasan perumahan berstrata dan tidak berstrata. Pada tahun 1961, bilangan kampung yang terdapat di seluruh Negeri Sembilan ialah 324 buah kampung. Namun begitu, pada tahun 2014, seiring dengan pertambahan populasi, bilangan kampung meningkat kepada 1690 buah kampung. 


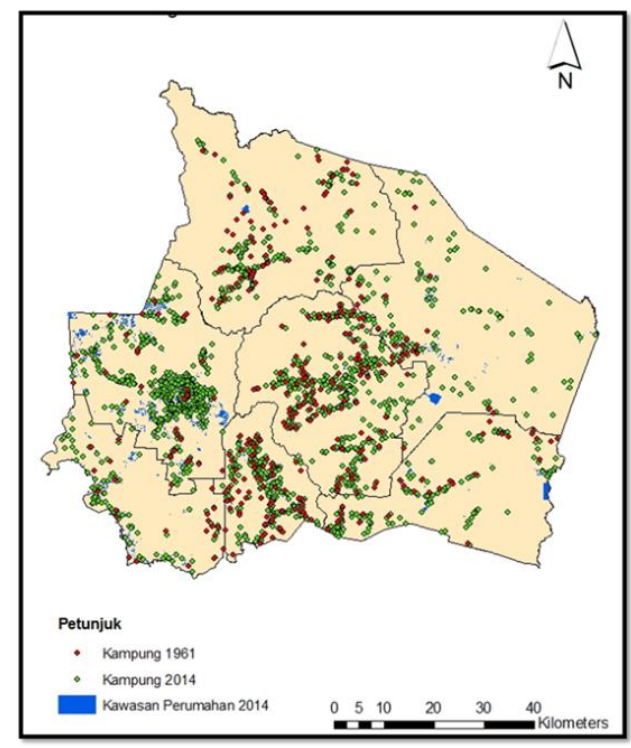

Rajah 5. Peta bilangan kampung dan kawasan perumahan Negeri Sembilan tahun 1961 dan 2014

Peningkatan populasi penduduk mempunyai kaitan yang rapat dengan guna tanah bandar. Pada tahun 1961, guna tanah bandar hanya wujud di kawasan-kawasan tertentu di Negeri Sembilan iaitu merangkumi hanya $0.73 \%$ dari keseluruhan negeri. Seiring dengan pertambahan penduduk, guna tanah bandar semakin berkembang dan bandar-bandar utama mula bertapak sehingga tahun 2014 di Negeri Sembilan. Antara bandar-bandar tersebut ialah bandar Seremban Jaya, bandar Johol, bandar Rompin dan bandar Pajam. Ini bermakna, perubahan guna tanah telah menyumbang kepada proses urbanisasi dan pertambahan penduduk di Negeri Sembilan

\section{c. Jaringan pengangkutan}

Sistem jaringan pengangkutan juga merupakan salah satu faktor berlakunya perubahan guna tanah di Negeri Sembilan. Sesebuah petempatan wujud dengan adanya jaringan pengangkutan yang dapat menghubungkan sesuatu tempat ke sesuatu tempat yang lain dan membolehkan interaksi ruangan berlaku (Deya Qtiashat et al., 2018). Pada tahun 1961, pembinaan jalan raya terbatas kepada beberapa kawasan utama. Jaringan jalan raya yang terbatas menyebabkan kadar ketersampaian penduduk terhadap barangan, kemudahan, maklumat dan keperluan asas menjadi terhad. 


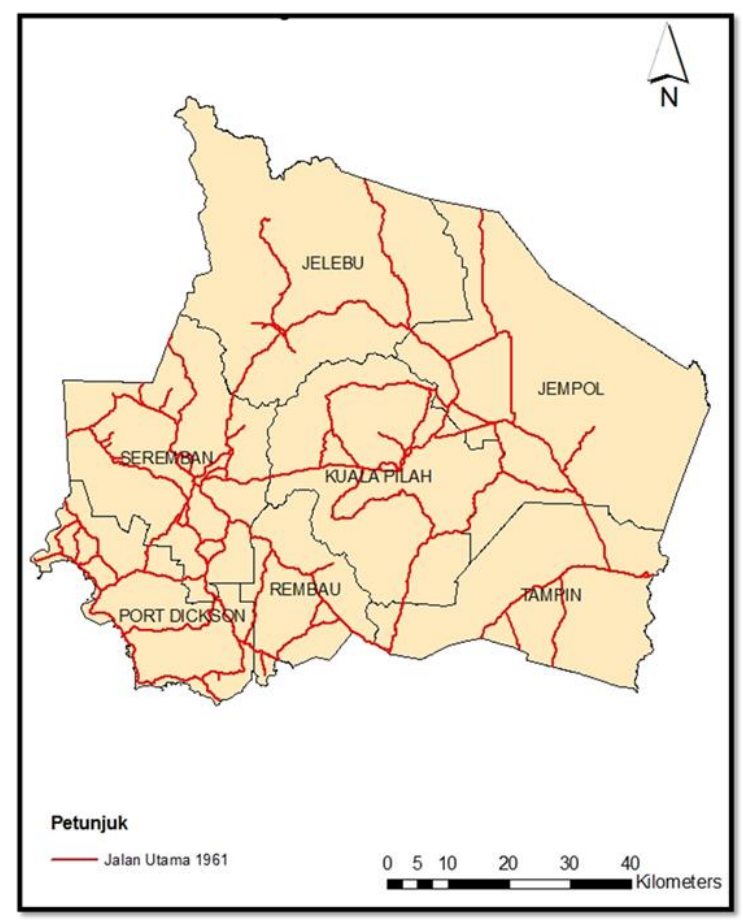

Rajah 6. Peta jaringan jalan raya utama Negeri Sembilan, 1961

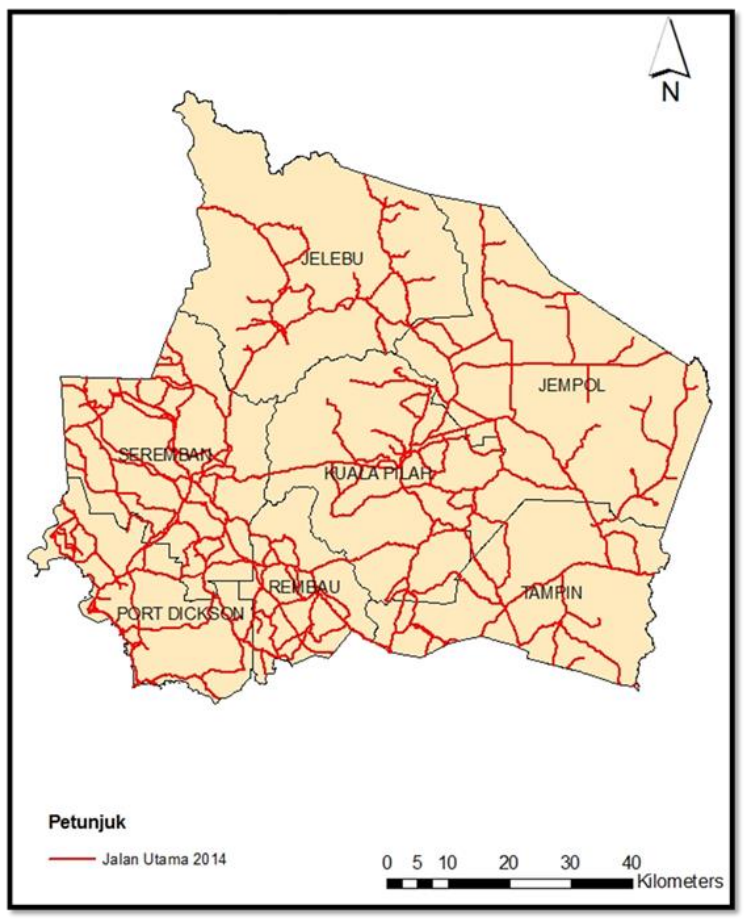

Rajah 7. Peta jaringan jalan raya utama Negeri Sembilan, 2014

Rajah 6 menunjukkan jaringan jalan raya pada tahun 1961. Rajah 7 pula menunjukkan jaringan jalan raya utama yang tersedia pada tahun 2014 di Negeri Sembilan. Pertambahan bilangan jalan raya utama pada tahun 2014 berupaya menghubungkan daerah-daerah di Negeri Sembilan dengan lebih efisien berbanding tahun 1961. Kewujudan jalan raya telah mempengaruhi perubahan guna tanah yang juga menyebabkan berlakunya perubahan terhadap kawasan sekitarnya

\section{d. Pembangunan ekonomi}

Malaysia merupakan sebuah negara membangun yang mengalami pembangunan yang semakin pesat. Pelbagai dasar seperti Dasar Ekonomi Baru dan Dasar Pembangunan Nasional diperkenalkan menyebabkan negeri-negeri di Malaysia menjalani perubahan daripada pelbagai aspek termasuk Negeri Sembilan. Faktor ekonomi sememangnya memberi impak yang besar kepada perubahan guna tanah yang berlaku di Negeri Sembilan pada tahun 1961 dan tahun 2014. Pertumbuhan Keluaran Dalam Negara Kasar (KDNK) Negeri Sembilan pada tahun 2012 ialah sebanyak $6.2 \%$ berbanding $5.2 \%$ pada tahun 2011. Hal ini menunjukkan telah berlaku peningkatan melalui komitmen terancang dalam membangunkan pelbagai sektor secara holistik bagi memacu ekonomi negeri (Utusan Malaysia Online, 2013). Oleh itu, ini membuktikan bahawa sememangnya Negeri Sembilan merupakan sebuah negeri yang sedang pesat berkembang dari segi ekonomi. Namun begitu, kepesatan dalam pertumbuhan ekonomi telah menuntut perubahan guna tanah berlaku. Antara sektor ekonomi yang membawa kepada perubahan guna tanah di Negeri Sembilan ialah pertanian, perindustrian dan pelancongan. 


\section{(1) Pembangunan sektor pertanian}

Pertanian merupakan antara penyumbang terbesar ekonomi di Negeri Sembilan. Hasil perbandingan yang dilakukan terhadap peta guna tanah Negeri Sembilan 1961 dan 2014, ternyata berlaku peningkatan yang mendadak dalam guna tanah pertanian. Misalnya, di bahagian timur daerah Jempol (Rajah 8), hampir keseluruhan kawasan hutan pada tahun 1961 telah ditukar kepada kawasan pertanian dan guna tanah bandar pada tahun 2014 bagi menyokong aktiviti pertanian yang dijalankan.

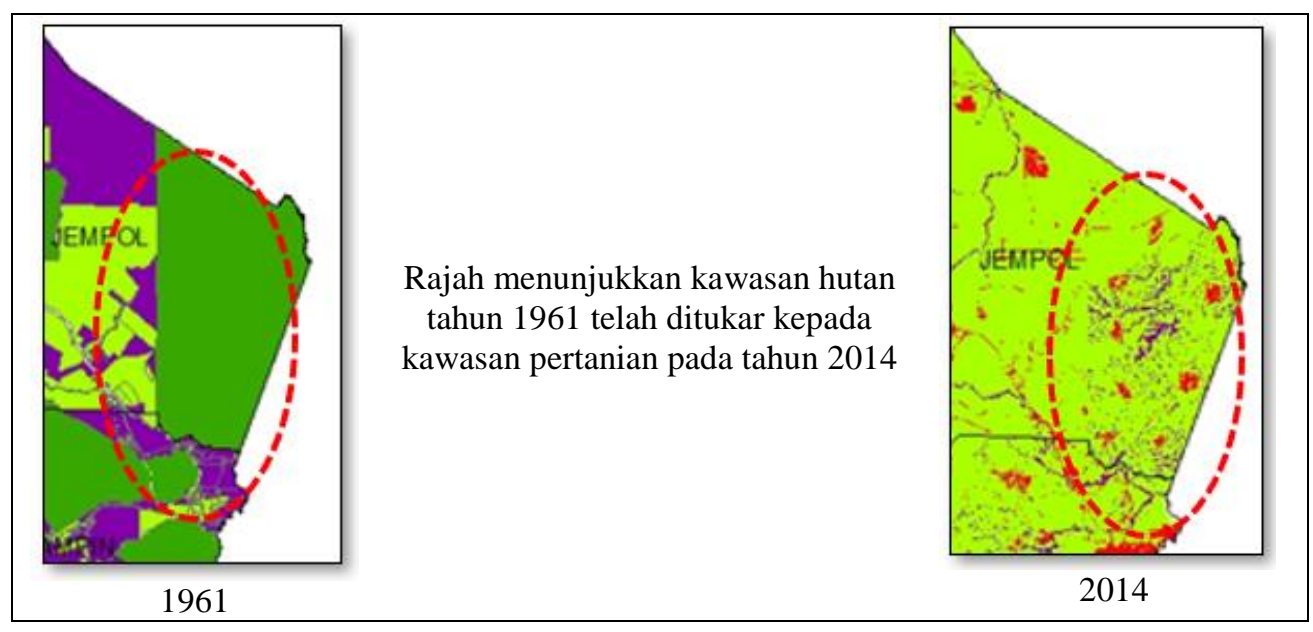

Rajah 8. Perubahan kawasan hutan kepada guna tanah pertanian dan perbandaran

Keluasan kawasan penanaman bagi sesuatu aktiviti pertanian adalah bergantung kepada sumbangan tanaman tersebut kepada ekonomi negara. Pada tahun 1961, jumlah keluasan bagi kawasan pertanian ialah $2381.14 \mathrm{~km}^{2}$. Rancangan Struktur Negeri Sembilan 2001-2020 meramalkan bahawa keluasan kawasan pertanian di negeri tersebut akan mengalami penurunan pada tahun 2005, 2010, 2015 dan 2020. Namun begitu, berdasarkan pengiraan daripada pemetaan yang telah dijalankan, keseluruhan keluasan kawasan pertanian menunjukkan peningkatan yang memberangsangkan iaitu $4076.17 \mathrm{~km}^{2}$ pada tahun 2014. Dasar Pertanian Negara yang diperkenalkan pada tahun 1984 yang bermatlamatkan untuk meningkatkan pendapatan telah membawa kepada pembukaan kawasan-kawasan pertanian baru dan penanaman tanaman komoditi seperti kelapa sawit secara besar-besaran. Oleh itu, beberapa siri Dasar Pertanian Negara yang diperkenalkan oleh kerajaan telah memberi impak yang besar terhadap perubahan guna tanah sesuatu kawasan.

\section{(2) Pembangunan sektor pelancongan}

Pelancongan merupakan antara penyumbang utama ekonomi di Negeri Sembilan. Kawasan pelancongan yang menyediakan kemudahan dan infrastruktur yang baik merupakan antara faktor penarik untuk pelancong berkunjung ke kawasan tersebut. Kesannya, membawa kepada peningkatan guna tanah perbandaran di Negeri Sembilan. Setiap daerah mempunyai kawasan tumpuan pelancong dan tarikannya yang tersendiri. Misalnya, daerah Port Dickson menawarkan konsep pelancongan pinggir pantai, manakala daerah Rembau pula lebih kepada pelancongan adat, budaya masyarakat dan sejarah. 


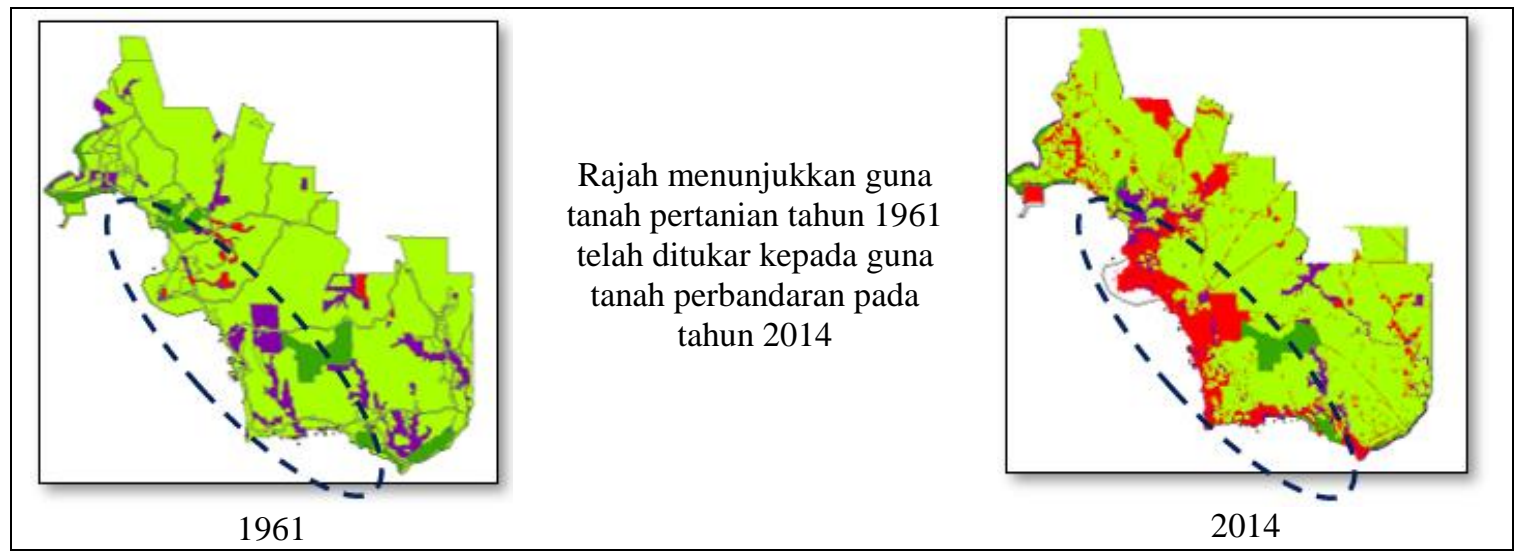

Rajah 9. Perubahan guna tanah pertanian kepada guna tanah perbandaran

Pinggir pantai Port Dickson yang merupakan guna tanah pertanian pada tahun 1961 telah berubah kepada guna tanah perbandaran pada tahun 2014 (Rajah 9). Hal ini jelas menunjukkan bahawa sektor pelancongan sememangnya telah memberi kesan kepada perubahan guna tanah di Negeri Sembilan. Qihao (2000) dalam kajiannya di China mendapati bahawa perubahan guna tanah yang pesat berlaku di pinggir pantai kesan daripada peningkatan dalam guna tanah perbandaran telah menyebabkan guna tanah pertanian semakin merosot di kawasan pinggir pantai.

\section{(3) Pembangunan sektor perindustrian}

Sektor perindustrian kini merupakan sektor yang mempunyai nilai yang sangat tinggi. Negeri Sembilan kini semakin giat memperkembangkan sektor perindustrian kerana pulangan ekonomi yang amat memberansangkan. Berikut merupakan rumusan daripada Rancangan Struktur Negeri Sembilan 2001-2020 jenis industri di Negeri Sembilan mengikut daerah (Jadual 4).

Jadual 4. Jenis industri mengikut daerah di Negeri Sembilan

\begin{tabular}{ll}
\hline Daerah & \multicolumn{1}{c}{ Jenis industri } \\
\hline Seremban & $\begin{array}{l}\text { Merangkumi semua jenis industri tetapi industri pembuatan utama ialah keluaran logam, } \\
\text { pembuatan jentera, elektrik dan elektronik, keluaran plastik dan pembuatan makanan } \\
\text { Keluaran logam, pembuatan perabot dan keluaran } \\
\text { Kualian bukan logam }\end{array}$ \\
Rembau & Pembuatan makanan dan keluaran perabot \\
Tampin & Kayu, logam dan pembuatan makanan \\
Jelebu & Kayu dan pembuatan makanan \\
Port Dickson & Keluaran petroleum \\
Jempol & Pembuatan makanan, kayu dan logam \\
Sumber: Jabatan Perancangan Bandar dan Desa Negeri Sembilan, 2007
\end{tabular}

Rajah 10 menunjukkan bahawa pada tahun 1961 guna tanah pertanian telah mendominasi daerah Seremban. Namun, pada tahun 2014, beberapa kawasan pertanian telah digantikan dengan kawasan industri yang merupakan guna tanah bandar. Ternyata bahawa sektor perindustrian sememangnya memberi kesan kepada perubahan guna tanah di Negeri Sembilan dalam tempoh 1961 sehingga 2014. 


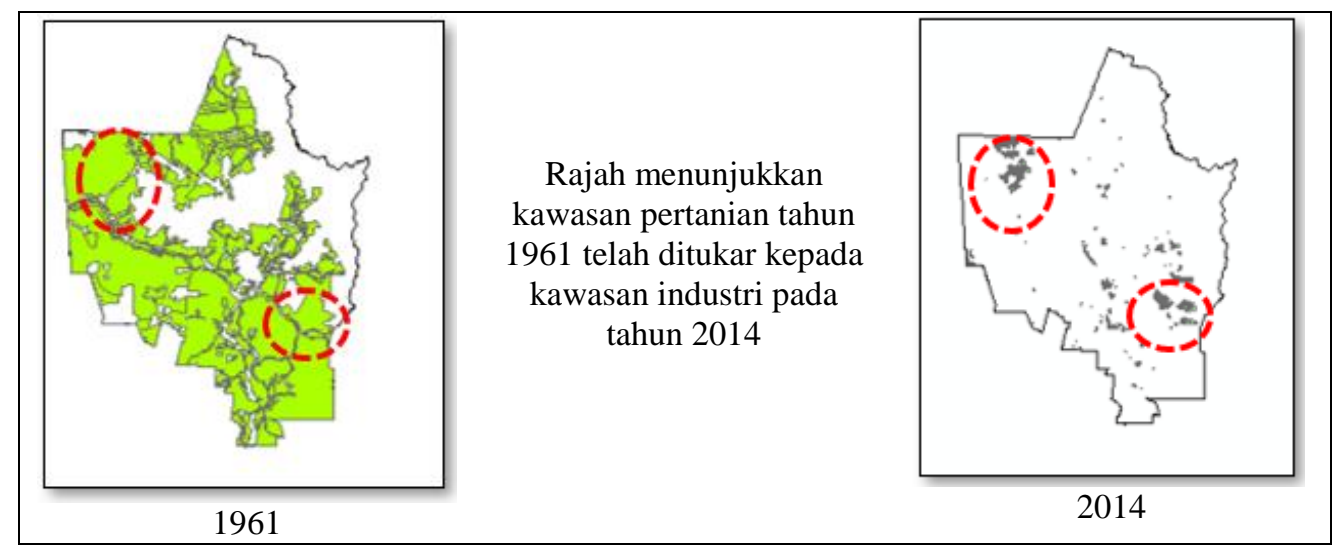

Rajah 10. Perubahan kawasan pertanian kepada kawasan perindustrian

\section{e. Konurbasi Kuala Lumpur}

Kewujudan Konurbasi Kuala Lumpur merupakan salah satu faktor yang menyebabkan berlakunya perubahan guna tanah di Negeri Sembilan terutama di daerah-daerah tertentu. Menurut Dasar Perbandaran Negara, konurbasi bermaksud sebagai kawasan bandar yang merangkumi beberapa bandaraya atau bandar yang bercantum secara fizikal dan membentuk satu kawasan tepubina berikutan pertambahan penduduk. Sempadan konurbasi adalah mengikut tempoh perjalanan dari tempat kerja ke pusat bandaraya, iaitu 45 minit bagi konurbasi utama dan 30 minit bagi konurbasi lain. Konurbasi Kuala Lumpur meliputi beberapa kawasan di dua daerah utama Negeri Sembilan iaitu Seremban dan Port Dickson (Jadual 5). Jadual 5 menunjukkan bahawa Seremban dan Port Dickson masing-masing berkeluasan 57345.945 hektar dan 95 187.396 hektar di dalam konurbasi Kuala Lumpur. Kesan daripada konurbasi yang berlaku menyebabkan kemajuan yang berpusat di Kuala Lumpur turut melimpah sehingga ke Seremban dan Port Dickson. Kawasan industri dan perumahan mula berkembang maju di dua daerah tersebut pada tahun 2014 berbanding tahun 1961 dan membawa kepada wujudnya perubahan guna tanah.

Jadual 5. Kawasan konurbasi Kuala Lumpur

\begin{tabular}{lcc}
\hline Negeri & Daerah & Keluasan (Hektar) \\
\hline Wilayah Persekutuan Kuala Lumpur & & $24,202.244$ \\
Wilayah Persekutuan Putrajaya & & $4,388.459$ \\
Selangor & Gombak & $62,820.101$ \\
& Hulu Langat & $83,955.544$ \\
& Hulu Selangor & $175,606.121$ \\
& Klang & $63,249.997$ \\
& Kuala Selangor & $85,839.592$ \\
& Petaling & $119,453.526$ \\
Negeri Sembilan & Sepang & $55,733.967$ \\
& Port Dickson & $57,345.945$ \\
Pahang & Seremban & $95,187.396$ \\
\hline
\end{tabular}

Sumber: Jabatan Perancangan Bandar dan Desa, Semenanjung Malaysia, 2010 


\section{Kesimpulan}

Hasil kajian mendapati guna tanah pertanian mempunyai perubahan paling tinggi dari tahun 1961 sehingga 2014 iaitu peningkatan sebanyak 24.66\%, manakala guna tanah perbandaran mempunyai perubahan paling rendah iaitu peningkatan hanya sejumlah $10.07 \%$. Faktor yang mendorong perubahan guna tanah di Negeri Sembilan ialah pengenalan Akta Perancangan Bandar dan Desa 1976, pertambahan populasi penduduk, jaringan pengangkutan, ekonomi dan konurbasi bandar Kuala Lumpur. Penyelidikan boleh terus dijalankan terhadap kawasan-kawasan di Negeri Sembilan. Sebarang perubahan guna tanah yang dilakukan harus diteliti kesannya kepada persekitaran manusia dan fizikal. Perubahan yang berlaku sememangnya akan memberi kesan positif terhadap ekonomi. Namun begitu perubahan guna tanah juga haruslah menepati syarat Environmental Impact Assesment (EIA) agar alam sekitar fizikal sentiasa terpelihara, walaupun wujud pembangunan dan perubahan guna tanah. Pemerhatian jangka panjang serta pemetaan ruangan guna tanah adalah penting untuk menilai dimensi, akibat serta sebab berlakunya perubahan dan bagi meramalkan perubahan yang bakal berlaku pada masa hadapan. Kajian ini dilihat dapat membantu dalam proses pembuatan keputusan bagi mengawal perubahan dan perancangan guna tanah yang berlaku di Negeri Sembilan dalam kaedah yang lebih sistematik dan memastikan kemampanan alam sekitar secara berterusan.

\section{Rujukan}

Bajocco, S., De Angelis, A., Perini, L., Ferrara, A., \& Salvati, L. (2012). The impact of land use/land cover changes on land degradation dynamics: A Mediterranean case study. Environmental Management, 49(5), 980-989.

Bakr, N., Weindorf, D.C., Bahnassy, M.H., Marei, S.M., \& El-Badawi, M.M. (2010). Monitoring land cover changes in a newly reclaimed area of Egypt using multi-temporal Landsat data. Applied Geography, 30(4), 592-605.

Basavarajappa, H.T., Dinakar, S., \& Manjunatha M.C. (2014). Analysis on land use/land cover classification around Mysuru and Chamarajanagara District, Karnataka, India, using IRS-1D PAN+ LISS-III satellite data. Journal Impact Factor, 5(11), 79-96.

Best, R.H. (1981). Land use and living space. London, Methuen.

Bičík, I., Kupková, L., Jeleček, L., Kabrda, J., Štych, P., Janoušek, Z., \& Winklerová, J. (2015). Land use changes in the Czech Republic 1845-2010: Socio-economic driving forces. Switzerland, Springer.

Christopoulou, O., Polyzos, S., \& Minetos, D. (2007). Peri-urban and urban forests in Greece: Obstacle or advantage to urban development? Management of Environmental Quality: An International Journal, 18(4), 382-395.

Dewan, A.M., \& Yamaguchi, Y. (2009). Using remote sensing and GIS to detect and monitor land use and land cover change in Dhaka Metropolitan of Bangladesh during 19602005. Environmental Monitoring and Assessment, 150(1-4), 237-249.

Deya Qtiashat, Zeyad Makhmreh, Hala Abu Taleb \& Ahmed Khalaifat. (2018). Urban land use pattern and road network characteristics using GIS in Al Salt City, Jordan. Modern Applied Science, 12(4), 128-142.

Jabatan Perancangan Bandar dan Desa Negeri Sembilan. (2007). Rancangan Struktur Negeri Sembilan 2001-2020. Kuala Lumpur, Jabatan Perancangan Bandar dan Desa. 
Jabatan Perancangan Bandar dan Desa Semenanjung Malaysia. (2010). Ringkasan eksekutif rangka kerja penyelarsan pengurusan Kuala Lumpur Conurbation. Kuala Lumpur, Jabatan Perancangan Bandar dan Desa.

Jabatan Perancangan Bandar dan Desa Negeri Sembilan. (2014). Rancangan Struktur Negeri Sembilan 2001-2020. Kuala Lumpur, Jabatan Perancangan Bandar dan Desa.

Jabatan Perancangan Bandar dan Desa Terengganu. (2018). Rancangan Struktur Negeri. Retrieved from http://jpbdtrg.gov.my.

Jabatan Perangkaan Malaysia. (2016). Unjuran Penduduk Negeri Sembilan. Kuala Lumpur, Jabatan Perangkaan Malaysia.

Jeffers, J. (1988). Decision-thinking about land use. Land Use Policy, 5(1), 75-78.

Jomaa, I., Auda, Y., Saleh, B.A., Hamze, M., \& Safi, S. (2008). Landscape spatial dynamics over 38 years under natural and anthropogenic pressures in Mount Lebanon. Landscape and Urban Planning, 87(1), 67-75.

Kementerian Perumahan dan Kerajaan Tempatan. (1976). Akta Perancangan Bandar dan Desa (Akta 172). Kuala Lumpur, Percetakan Kerajaan Malaysia.

Kleeman, J., Baysal, G., Bulley, H.N., \& Fürst, C. (2017). Assessing driving forces of land use and land cover change by a mixed-method approach in north-eastern Ghana, West Africa. Journal of Environmental Management, 196, 411-442.

La Mela Veca, D.S., Cullotta, S., Sferlazza, S., \& Maetzke, F.G. (2016). Anthropogenic influences in land use/land cover changes in Mediterranean forest landscapes in Sicily. Land, 5(1), 3.

Lam, K.C., \& Nik Nurul Hidaya Mohd Noor. (2018). Kajian perubahan guna tanah menerusi aplikasi penderiaan jauh. Geografia-Malaysian Journal of Society and Space, 14(2), 108124.

Lowicki, D. (2008). Land use changes in Poland during transformation: Case study of Wielkopolska region. Landscape and Urban Planning, 87(4), 279-288.

Meshesha, T.W., Tripathi, S.K., \& Khare, D. (2016). Analyses of land use and land cover change dynamics using GIS and remote sensing during 1984 and 2015 in the Beressa Watershed Northern Central Highland of Ethiopia. Modeling Earth Systems and Environment, 2(4), 112.

Mohd Hafiz Mohd Hazir, \& Tuan Mohamad Tuan Muda. (2016). Geospatial application for the identification and monitoring of rubber smallholders in the Malaysian state of Negeri Sembilan. IOP Conference Series; Earth and Environmental Science Vol. 37. IOP Publishing.

Narimah Samat. (2010). Assessing land use land cover changes in Langkawi island: Towards sustainable urban living. Malaysian Journal of Environmental Management, 11(1), 48-57.

Nedal A.Mohammad, Sharifah Mastura S.A., \& Johari Mat Akhir. (2007). Land use evaluation for Kuala Selangor, Malaysia using remote sensing and GIS technologies. GeografiaMalaysian Journal of Society and Space, 3, 1-18.

Nur Hakimah Asnawi., \& Lam, K.C. (2016). Analisis perubahan guna tanah dan litupan bumi di Gombak, Selangor menggunakan data penderiaan jauh. Sains Malaysiana, 45(12), 18691877.

Paul, V., \& Tonts, M. (2005). Containing urban sprawl: trends in land use and spatial planning in the metropolitan region of Barcelona. Journal of Environmental Planning and Management, 48(1), 7-35. 
Pei, B., \& Pan, T. (2010). Land use system dynamic modeling: Literature review and future research direction in China. Progress in Geography, 29(9), 1060-1066.

Petit, C.C., \& Lambin, E.F. (2002). Long-term land-cover changes in the Belgian Ardennes (1775-1929): Model-based reconstruction vs. historical maps. Global Change Biology, 8(7), 616-630.

Pijanowski, B.C., \& Robinson, K.D. (2011). Rates and patterns of land use change in the Upper Great Lakes States, USA: A framework for spatial temporal analysis. Landscape and Urban Planning, 102(2), 102-116.

Pourebrahim, S., Hadipour, M., \& Mazlin Mokhtar. (2015). Impact assessment of rapid development on land use changes in coastal areas: Case of Kuala Langat district, Malaysia. Environment, Development and Sustainability, 17(5), 1003-1016.

Putman, S.H. (1975). Urban land use and transportation models: A state-of-the-art summary. Transportation Research, 9(2-3), 187-202.

Qihao, W. (2002). Land use change analysis in the Zhujiang Delta of China using satellite remote sensing, GIS and stochastic modelling. Journal of Environmental Management, 64(3), 273-284.

Rajan, K.S., \& Shibasaki, R. (2001). A GIS based integrated land use/cover change model to study agricultural and urban land use changes. The 22nd Asian Conference on Remote Sensing Vol. 5. 9.

Reis, S. (2008). Analyzing land use/land cover changes using remote sensing and GIS in Rize, North-East Turkey. Sensors, 8(10), 6188-6202.

Rhind, D., \& Hudson, R. (1980). Land use. United Kingdom, Routledge.

Soliman, A.M. (2004). Regional planning scenarios in South Lebanon: The challenge of ruralurban interactions in the era of liberation and globalization. Habitat International, 28(3), 385-408.

Statuto, D., Cillis, G., \& Picuno, P. (2016). Analysis of the effects of agricultural land use change on rural environment and landscape through historical cartography and GIS tools. Journal of Agricultural Engineering, 47(1), 28-39.

Ting, L., \& Xiaojun, Y. (2015). Monitoring land changes in an urban area using satellite imagery, GIS and landscape metrics. Applied Geography, 56, 42-54.

Tuan Pah Rokiah Syed Hussain \& Hamidi Ismail (2016) Perubahan gunatanah dan kejadian banjir di Lembangan Saliran Kelantan. Geografia-Malaysian Journal of Society and Space, 12(1), 118-128.

Utusan Malaysia Online. (2013). Negeri Sembilan peneraju ekonomi baik negara. Retrieved from http://www.utusan.com.my.

Wolman, M.G., \& Fournier, F.G.A. (1987). Land transformation in agriculture. Great Britain, John Wiley and Sons.

Xia, T., Wu, W., Zhou, Q., Tan, W., Verburg, P.H., Yang, P., \& Ye, L. (2018). Modeling the spatio-temporal changes in land uses and its impacts on ecosystem services in Northeast China over 2000-2050. Journal of Geographical Sciences, 28(11), 1611-1625.

Yafei, L., \& Gaohuan, L. (2017). Characterizing spatiotemporal pattern of land use change and its driving force based on GIS and landscape analysis techniques in Tianjin during 20002015. Sustainability, 9(6), 894.

Yong, F., Guangming, Y., Zongyi, H., Hailong, Y., Rui, B., Linru, Y., \& Di, W. (2017). Entropies of the Chinese land use/cover change from 1990 to 2010 at a county level. Entropy, 19(2), 51. 
Yuan, F. (2008). Land-cover change and environmental impact analysis in the Greater Mankato area of Minnesota using remote sensing and GIS modelling. International Journal of Remote Sensing, 29(4), 1169-1184.

Zhao, L.L., He, D.J., Tan, D.H., You, W.B., Hong, W., \& Fan, X.C. (2017). Dynamic changes of land use in coastal zone of eastern Fujian from 2000 to 2014. Chinese Journal of Tropical Crops, 38(5), 803-810.

Zimu, J., Bingran, M., Jing, Z., \& Weihua, Z. (2018). Simulating spatial-temporal changes of land-use based on ecological redline restrictions and landscape driving factors: A case study in Beijing. Sustainability, 10(4), 1299.

Zurinah Tahir, \& Jalaludin Abdul Malek. (2017). Pemantauan percanggahan guna tanah bandar dan tanah pertanian menggunakan Sistem Maklumat Geografi (GIS). Geografia-Malaysian Journal of Society and Space, 13(3), 112-130. 